\title{
Sex-Dependent Regulation of Estrogen Receptor $\beta$ in Human Colorectal Cancer Tissue and its Relationship With Clock Genes and $V E G F-A$ Expression
}

\author{
I. HERICHOVA ${ }^{1 *}$, R. REIS $^{2}$, K. HASAKOVA ${ }^{1}$, M. VICIAN ${ }^{3}$, M. ZEMAN $^{1}$ \\ * These authors contributed equally to this work.
}

${ }^{1}$ Department of Animal Physiology and Ethology, Faculty of Natural Sciences, Comenius

University, Bratislava, Slovak Republic, ${ }^{2}$ First Surgery Department, University Hospital, Comenius University Bratislava, Bratislava, Slovak Republic, ${ }^{3}$ Fourth Surgery Department, University Hospital, Comenius University Bratislava, Bratislava, Slovak Republic

Received March 22, 2019

Accepted October 4, 2019

\section{Summary}

The incidence of colorectal cancer (CRC) shows a sex-dependent difference in humans. The aim of this study was to analyze estrogen receptor $\beta$ mRNA ( $E R \beta$ ) expression in patients with CRC with respect to their gender and clinicopathological features. Since cancer progression is accompanied by tumor vascularization, VEGF-A (vascular endothelial growth factor $A$ ) transcription was analyzed along with ER $\beta$ mRNA. ER $\beta$ mRNA was also correlated with the expression of clock genes, which are known to influence the cell cycle. ER $\beta$ mRNA expression in females with CRC showed an inverse association with increasing tumor staging that was not observed in males. Lower levels of $E R \beta$ mRNA were observed in females with a higher clinical stage compared with those with earlier-stage tumors. $E R \beta$ mRNA expression showed a significant positive correlation with mRNA of clock genes period 2 and cryptochrome 2 in healthy but not in cancerous tissue in males. Expression of VEGF-A mRNA showed a negative correlation with $E R \beta \mathrm{mRNA}$ after splitting of the cohort according to gender and nodus involvement. We propose that gender differences in $E R \beta$ mRNA expression in tumors during the early stages of CRC can partially explain the lower occurrence of $\mathrm{CRC}$ in females compared with males.

\section{Key words}

PER2 • CRY1 • CRY2 • Angiogenesis • Circadian

\section{Corresponding author}

I. Herichova, Department of Animal Physiology and Ethology, Faculty of Natural Sciences, Comenius University Bratislava,
Ilkovicova 6, 84215 Bratislava, Slovak Republic. E-mail: herichova1@uniba.sk

\section{Introduction}

Epidemiological data clearly indicate that the incidence of colorectal cancer (CRC) is higher in males than in females. A sex-dependent difference in CRC incidence was reported at all anatomic subsites, with the male-to-female incidence rate ratio increasing progressively across the colon from the cecum to the rectum (Murphy et al. 2011, Torre et al. 2012, Siegel et al. 2015).

The higher frequency of CRC diagnosis in males is usually attributed to sex steroid hormones. Estrogen in particular is proposed to exert beneficial effects as a hormone-replacement therapy in postmenopausal females and is associated with a reduced risk of CRC and increased survival (Symer et al. 2018, Nie et al. 2018). In humans, estrogen exerts its effects via estrogen receptor $\alpha$ and $\beta \quad(E R \alpha$ and $E R \beta$, respectively). While ER $\alpha$-mediated effects have been studied extensively with respect to several types of cancer (Clocchiatti et al. 2016), the functions of ER $\beta$ have not been completely elucidated. In the colon, mRNA expression of $E R \beta$ is much more abundant than that of ER $\alpha$ (Foley et al. 2000, Kennelly et al. 2008, Williams et al. 2016); therefore, effects of estradiol exerted in this tissue are usually attributed to $E R \beta$ signaling (Clocchiatti et al. 2016). 
It has been shown that overexpression of $E R \beta$ results in inhibition of proliferation and G1 phase cell cycle arrest in SW480 colon cancer cells. Overexpression of $E R \beta$ was also accompanied by downregulation of Myc proto-oncogene protein expression (Hartman et al. 2009). $E R \beta$ knockout in mice was associated with decreased apoptosis, an increased proliferation rate and abnormalities in the structure of intercellular junctions (Wada-Hiraike et al. 2006). Estrogen has been reported to play an important role in maintaining the function of the gastrointestinal epithelial barrier, e.g. by increasing occludin and junctional adhesion molecule-A expression (Nie et al. 2018). In mice that spontaneously develop intestinal adenomas because of a nonsense mutation in the Apc gene, deletion of $E R \beta$ leads to an increased size and number of adenomas (Giroux et al. 2008), and a selective $E R \beta$ agonist reversed this effect (Giroux et al. 2011).

Tumor growth is accompanied by production of novel vascularization, which is stimulated by VEGF (vascular endothelial growth factor) signaling (ClaessonWelsh and Welsh 2013). Expression of VEGF-A mRNA was increased in colorectal carcinoma compared with normal mucosa, and higher levels of $V E G F-A$ mRNA were observed in tumors with lymph node metastases compared with non-metastatic tumors (George et al. 2001). An association between negative or low expression of VEGF in tumor tissue and better survival was also observed in patients with CRC (Bendardaf et al. 2017).

Angiogenesis that accompanies tumor expansion is inhibited by ER $\beta$. In mice with implanted T47D breast cancer cells, an ER $\beta$-mediated decrease in VEGF release and a reduction in intratumoral vascularization and tumor growth were observed (Hartman et al. 2006). In the colon estrogen has been shown to reduce the multiplicity and volume of dimethylhydrazine-induced polyps and decrease VEGF expression (Yang et al. 2013). These effects are probably mediated via estrogen response elements present in the VEFG sequence (Hyder et al. 2000).

Another modulation of CRC progression is associated with the functioning of the circadian system (Yang et al. 2017). The molecular principle of circadian oscillator function is based on clock gene expression creating a basic feedback loop. In humans a negative component of the feedback loop is created by period 1-3 (PER) genes and cryptochrome 1-2 (CRY) genes, while the positive arm is composed of transcriptional factors BMAL1 (brain and muscle ARNT-Like protein 1) and CLOCK (circadian locomotor output cycles kaput). Genes involved in basic loop functioning are able to mediate oscillations via several regulatory domains (including abundantly spread E-box) into the transcriptome (Honma 2018). ER $\beta$ mRNA expression is under circadian system control via an E-box present in its promoter (Cai et al. 2008), and VEGF shows a rhythmic pattern in several types of in vivo implanted tumor cell lines and livers of mice (Koyanagi et al. 2003). Clock genes have also been shown to influence cell cycle progression (Gaucher et al. 2018). A role for clock genes in tumor development was supported by a study showing that polymorphic variants of core clock genes of the circadian oscillator are associated with several types of cancer, including colorectal cancer (Valenzuela et al. 2016).

ER $\beta$ mRNA expression has been previously shown to exhibit a sex-dependent association with patient survival (Hasakova et al. 2018). A sex-dependent role of the circadian system in tumorigenesis was demonstrated in a study pointing out different survival rates in males and females depending on administration of chronomodulated chemotherapy (Giacchetti et al. 2012). Therefore, we focused on sex-dependent regulation of $E R \beta$ expression in CRC patients and analyzed it with respect to clock and $V E G F-A$ expression.

\section{Methods}

The cohort consisted of 64 patients of both genders that underwent surgery for colorectal cancer. Detailed clinicopathological characteristics of patients and tumors are provided in Table 1. All patients were exposed to standard hospital practice with lights on from 6:00 a.m. to 9:00 p.m. (The First Surgery Department, University Hospital, Comenius University, Bratislava). Tumor, proximal ( $\geq 10 \mathrm{~cm}$ from tumor) and distal $(\geq 2 \mathrm{~cm}$ from tumor) tissues were dissected during the surgery performed in a 2-h time window (10:00-12:00 a.m.). Sample collection was performed from 2008 to 2014. Follow-up lasted until 3 April 2018. Excised tissues were examined by a hospital pathologist to determine grading and staging. Tissue samples intended for gene expression analysis were frozen in liquid nitrogen and stored at $-70^{\circ} \mathrm{C}$ until mRNA extraction. All patients signed an informed consent, and the experimental protocol was approved by the Ethics committee. 
Table 1. Characteristics of the patient cohort.

\begin{tabular}{|c|c|c|c|}
\hline All patients & & $n=64$ & $\%$ \\
\hline \multirow{2}{*}{ Gender } & Male & 38 & 59.4 \\
\hline & Female & 26 & 40.6 \\
\hline Age & Mean \pm SEM (years) & \multicolumn{2}{|c|}{$69 \pm 1.4$} \\
\hline \multirow{2}{*}{ Tumor location } & Right-side & 25 & 39.1 \\
\hline & Left-side & 39 & 60.9 \\
\hline \multirow{3}{*}{ Grading stage } & Well differentiated & 11 & 17.2 \\
\hline & Moderately differentiated & 49 & 76.6 \\
\hline & Poorly differentiated & 4 & 6.3 \\
\hline \multirow{4}{*}{ Clinical stage } & $I$ & 4 & 6.3 \\
\hline & $I I A, I I B$ & 29 & 45.3 \\
\hline & IIIA, IIIB & 15 & 23.4 \\
\hline & $I V A, I V B$ & 16 & 25.0 \\
\hline \multicolumn{4}{|l|}{ TNM classification } \\
\hline \multirow{3}{*}{ Primary tumor invasion } & $T 1-T 2$ & 4 & 6.3 \\
\hline & $T 3$ & 48 & 75.0 \\
\hline & T4 & 12 & 18.8 \\
\hline \multirow{3}{*}{ Regional lymph node } & NO & 35 & 54.7 \\
\hline & N1 & 13 & 20.3 \\
\hline & $N 2$ & 16 & 25.0 \\
\hline \multirow{2}{*}{ Distant metastasis } & MO & 48 & 75.0 \\
\hline & $M 1$ & 16 & 25.0 \\
\hline
\end{tabular}

$\mathrm{n}$ - number, $\mathrm{T}$ - tumor invasion, $\mathrm{N}$ - nodal status, $\mathrm{M}$ - distant metastasis, SEM - standard error of the mean.

RNA from tumor and proximal and distal healthy tissues $(70 \mathrm{mg})$ was extracted with the use of RNAzol according to the manufacturer's instructions (MRC, USA). Synthesis of complementary DNA was performed with the ImProm-II Reverse Transcription System (Promega, USA) as described earlier (Herichova et al. 2014). To analyze gene expression QuantiTect SYBR Green PCR Kit with Sybr-green chemistry (QIAGEN, Germany) was used. Quantification was done by StepOnePlus ${ }^{\mathrm{TM}}$ Real-Time PCR System (Applied Biosystems, USA). Primers for the detection of PER2, $C R Y 1, C R Y 2, V E G F-A, E R \beta$ and U6 (U6 small nuclear RNA) were:

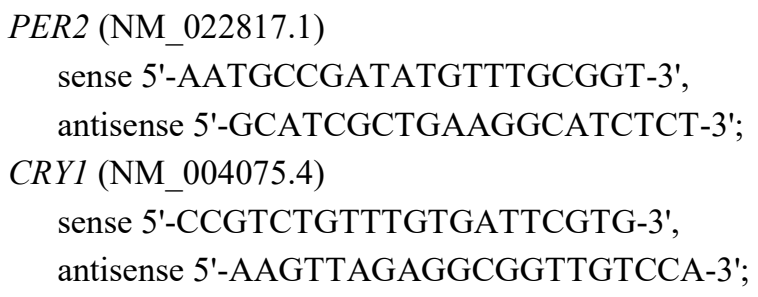

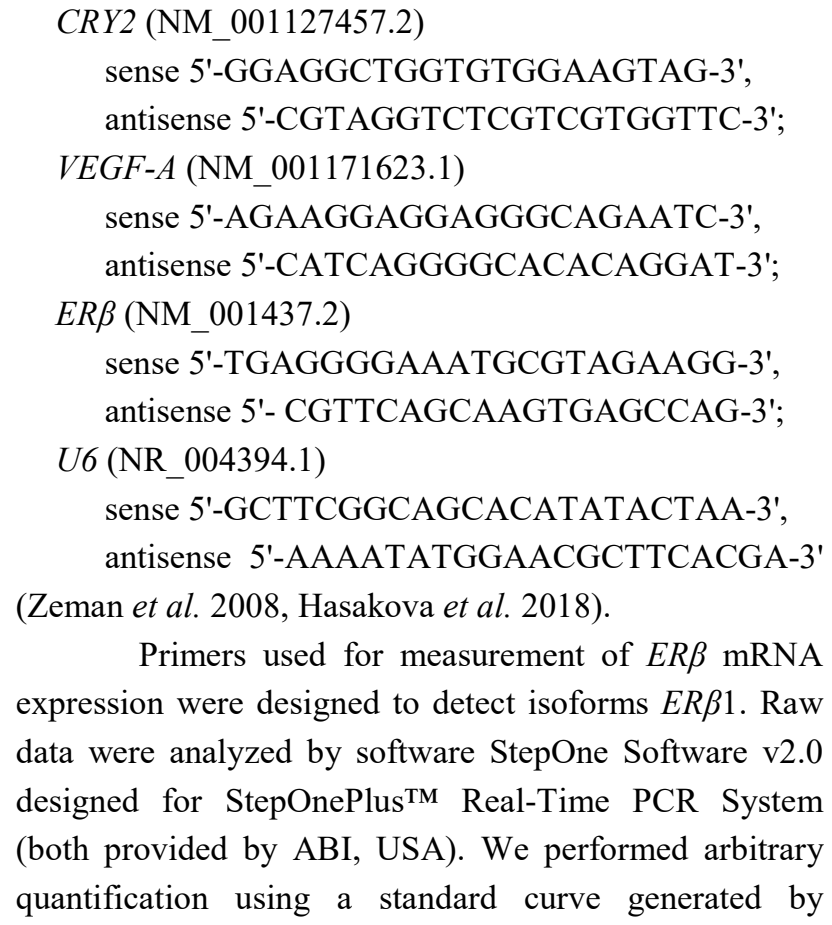

Primers used for measurement of $E R \beta$ mRNA expression were designed to detect isoforms $E R \beta 1$. Raw data were analyzed by software StepOne Software v2.0 designed for StepOnePlus ${ }^{\mathrm{TM}}$ Real-Time PCR System (both provided by ABI, USA). We performed arbitrary quantification using a standard curve generated by 
logarithmic dilution of a sample with high expression. The default threshold was 10 standard deviations above the mean fluorescence generated during baseline cycles (in most cases baseline was established from cycles 3-15). The threshold value was used to calculate the $\mathrm{Ct}$ values for each sample in the run for every gene separately.

Real time PCR conditions were as follows: activation of hot start polymerase at $95{ }^{\circ} \mathrm{C}$ for $15 \mathrm{~min}$ followed by $35-45$ cycles at $94{ }^{\circ} \mathrm{C}$ for $15 \mathrm{~s}, 49-53{ }^{\circ} \mathrm{C}$ for $30 \mathrm{~s}\left(49^{\circ} \mathrm{C}\right.$ for cryl, cry2, per2; $52{ }^{\circ} \mathrm{C}$ for $U 6 ; 53{ }^{\circ} \mathrm{C}$; vegf-a, $E R \beta)$ and $72{ }^{\circ} \mathrm{C}$ for $30 \mathrm{~s}$. Melting curve analysis and sequencing were used for validation of PCR product specificity. Nuclear RNA U6 was used for gene normalization.

\section{Statistical analysis}

The normality of the data distribution was confirmed by the Kolmogorov-Smirnov test. To evaluate $E R \beta$ mRNA expression with respect to tumor staging, the male and female parts of the cohort were split into three groups according to TNM (Tumor, Nodes, Metastases) classification. Group 1 consisted of patients without nodus involvement and distant metastases (T1-4N0M0), group 2 was composed of patients with nodus involvement and without distant metastases (T3-4N1-2M0) and group 3 involved patients with distant metastases (T3-4N0-2M1). Analysis of variance (ANOVA) with Tukey's post hoc test was performed to compare the three groups.

Regression analysis was performed to analyze the association of $E R \beta$ mRNA expression with the expression of clock genes and VEGF-A mRNA. Data are provided as mean \pm standard error of the mean (SEM). The threshold for significance was set at $\mathrm{P}<0.05$.

\section{Results}

Males comprised $59 \%$ and females $41 \%$ of the cohort. Mortality during the follow-up period was $53 \%$ in males and $54 \%$ in females.

The expression of ER $\beta$ mRNA in cancer tissue was evaluated with respect to TNM staging after splitting of the cohort into three groups. Group 1 consisted of patients without nodus involvement and distant metastases, group 2 was composed of patients with nodus involvement and without distant metastases and group 3 involved patients with distant metastases.

In females from group 1 , expression of $E R \beta$
mRNA in the cancer tissue did not differ from that measured in proximal and distal tissues. The decrease in $E R \beta$ mRNA expression in cancer tissue compared with healthy tissues was significant in groups 2 and 3 of the female part of the cohort (ANOVA, $\mathrm{P}<0.05, \mathrm{n}=7-10$ ). When the expression of $E R \beta$ mRNA in cancer tissue among groups 1-3 was compared, there was a significant difference between group 1 and group 3 (ANOVA, $\mathrm{P}<0.05, \mathrm{n}=7-10$, Fig. 1).

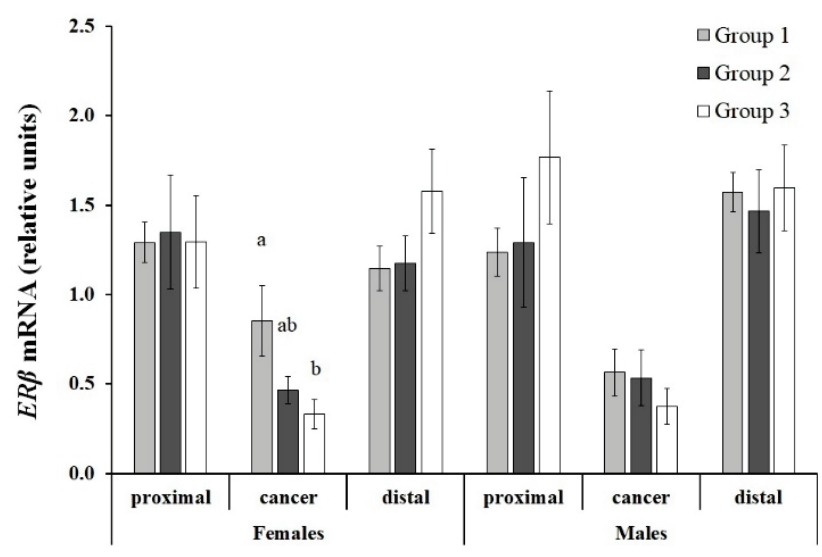

Fig. 1. Expression of estrogen receptor $\beta(E R \beta)$ in patients with colorectal cancer clustered into groups according TNM stage. Group 1 - patients without nodus involvement and distant metastases (gray columns); group 2 - patients with nodus involvement and without distant metastases (dark gray columns); group 3 - patients with distant metastases (white columns). Estrogen receptor $\beta$ (ERß) mRNA expression in tumors was compared among the three groups by ANOVA followed by Tukey's post hoc test $(n=7-10)$. Columns labeled with different letters $(a, b)$ indicate a significant difference between groups (Tukey's post hoc test, $\mathrm{P}<0.05)$. Data are provided as mean $\pm \mathrm{SEM}$.

Expression of ER $\beta$ mRNA in cancer tissue compared with proximal and distal tissues was significantly different between group 1 and group 3 (ANOVA, $\mathrm{P}<0.05, \mathrm{n}=9-24$ ) in males. The difference between cancer and healthy tissues achieved $\mathrm{P}=0.063$ (ANOVA, $n=5$ ) in group 2 of the male part of the cohort. Comparison of ER $\beta$ mRNA expression in cancer tissue among groups 1-3 did not show a significant difference (ANOVA) in males.

$E R \beta$ mRNA expression in healthy tissues was not significantly different in comparisons among groups 1-3 or between males and females (Fig. 1).

In females, decreasing values of $E R \beta$ mRNA expression were detected with increasing extent of nodus involvement. When the female part of the cohort was split according to the presence of nodus metastases, ANOVA showed significant differences $(\mathrm{P}<0.05, \mathrm{n}=6-10$, Fig. 2A). A post hoc test indicated a difference between 
females without nodus involvement and those with nodus metastases and/or distant metastases with $\mathrm{P}=0.053$ and 0.059 , respectively.

There was a significant difference between female clusters created according to clinical stage, implicating a negative correlation between $E R \beta$ expression and clinical stage (ANOVA, $\mathrm{P}<0.05, \mathrm{n}=7-10$, Fig. 2B). Dependence of $E R \beta$ on nodus involvement and clinical stage was not observed in men; however, there was a trend showing decreased $E R \beta$ expression in patients with high tumor size (data not shown).

We observed a positive correlation between the expression of $E R \beta$ and that of clock genes PER2 and $C R Y 2$ in male proximal tissue (regression analysis, $\mathrm{P}<0.05$, $\mathrm{n}=38$,
Table 2). There was no such correlation in cancer tissue.

The expression of $E R \beta$ in cancer tissue was significantly correlated with $V E G F-A$ expression after clustering of the cohort according to gender and nodus involvement. There was a significant correlation between $E R \beta$ and $V E G F-A$ expression in females without nodus involvement (regression analysis, $\mathrm{P}<0.05, \mathrm{n}=26$, Table 3 ) that diminished in the presence of metastases. In males a negative correlation between $E R \beta$ and $V E G F-A$ was present in patients with nodus metastases (regression analysis, $\mathrm{P}<0.05, \mathrm{n}=38$, Table 3 ) and not in an earlier stage of CRC. A negative correlation between $E R \beta$ and $V E G F-A$ was not observed in healthy tissues (regression analysis, data not shown).
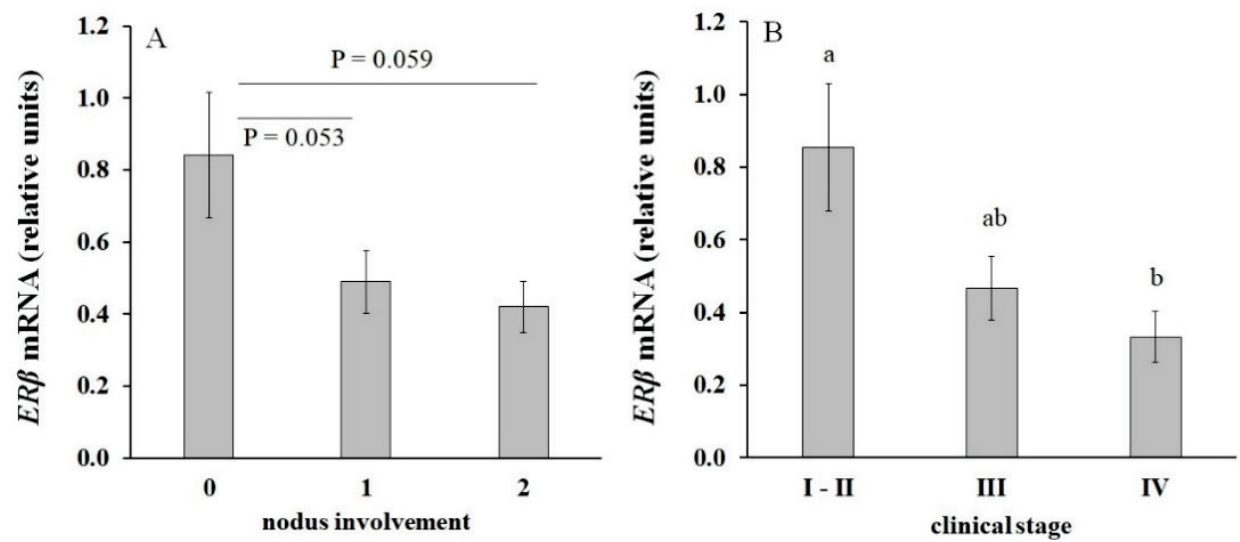

Fig. 2. Expression of estrogen receptor $\beta(E R \beta)$ in female patients with colorectal cancer clustered according to (A) nodus involvement and (B) clinical stage. Numbers below the $x$-axis indicate either presence/absence of nodus involvement $(A, n=6-10)$ or clinical stage $(B, n=7-10)$. In part $B$, clinical stages 1 and 2 were joined because of the low number of patients. ER $\beta$ mRNA expression in tumors was compared among the three groups by ANOVA followed by Tukey's post hoc test. Columns labeled with different letters ( $a, b)$ implicate a significant difference between groups (Tukey's post hoc test, $\mathrm{P}<0.05$ ). Data are provided as mean $\pm \mathrm{SEM}$.

Table 2. Association between the expression of estrogen receptor $\beta$ mRNA and that of clock genes and VEGF- $A$ mRNA.

\begin{tabular}{|c|c|c|c|c|c|c|}
\hline & & & PER2 & CRY1 & CRY2 & $V E G F-A$ \\
\hline \multirow{6}{*}{ Females } & \multirow{3}{*}{ Tumor tissue } & beta & 0.042 & -0.120 & 0.052 & -0.781 \\
\hline & & $R$ & 0.100 & -0.094 & 0.116 & -0.375 \\
\hline & & $P$ & ns & ns & ns & 0.059 \\
\hline & \multirow{3}{*}{$\begin{array}{c}\text { Proximal } \\
\text { tissue }\end{array}$} & beta & 0.039 & 0.007 & 0.045 & 0.006 \\
\hline & & $R$ & 0.171 & 0.012 & 0.163 & 0.022 \\
\hline & & $\boldsymbol{P}$ & ns & ns & ns & ns \\
\hline \multirow{6}{*}{ Males } & \multirow{3}{*}{ Tumor tissue } & beta & -0.005 & 0.000 & 0.008 & -0.004 \\
\hline & & $R$ & 0.224 & 0.168 & 0.123 & -0.255 \\
\hline & & $\boldsymbol{P}$ & ns & ns & ns & ns \\
\hline & \multirow{3}{*}{$\begin{array}{c}\text { Proximal } \\
\text { tissue }\end{array}$} & beta & 0.162 & 0.100 & 0.142 & 0.100 \\
\hline & & $R$ & 0.422 & 0.116 & 0.349 & 0.222 \\
\hline & & $P$ & 0.008 & ns & 0.032 & ns \\
\hline
\end{tabular}

PER - period, CRY - cryptochrome, VEGF - vascular endothelial growth factor, beta - slope of the regression line, R - regression coefficient, ns - not significant, $\mathrm{P}$ - probability value. 
Table 3. Association between the expression of $E R \beta$ and VEGF-A mRNA in tumor tissue clustered according gender and nodus involvement.

\begin{tabular}{lccccc}
\hline & & \multicolumn{3}{c}{ Tumor Tissue } \\
& & beta & $\mathrm{R}$ & $\mathbf{P}$ \\
\hline \multirow{3}{*}{ FEGF-A } & \multirow{2}{*}{ Females } & $N 0$ & -0.935 & -0.737 & $\mathbf{0 . 0 1 5}$ \\
& & $N 1-2$ & -0.874 & -0.136 & $\mathrm{~ns}$ \\
\cline { 2 - 5 } & \multirow{2}{*}{ Males } & $N 0$ & -0.342 & -0.140 & $\mathrm{~ns}$ \\
& & $N 1-2$ & -1.709 & -0.560 & $\mathbf{0 . 0 4 7}$ \\
\hline
\end{tabular}

VEGF - vascular endothelial growth factor, NO - without nodus involvement, N1-2 - lymph node metastasis present, beta - slope of the regression line, $\mathrm{R}$ - regression coefficient, $\mathrm{ns}-$ not significant, $\mathrm{P}-$ probability value.

\section{Discussion}

The most important finding of the present study is that $E R \beta$ mRNA expression in colorectal cancer shows sex-dependent regulation. Unlike in males, in females with CRC with neither nodus involvement nor distant metastases, ER $\beta$ mRNA expression in cancer tissue is not significantly decreased compared with healthy tissues. On the other hand, a progressive decline of $E R \beta$ mRNA expression in the cancer tissue begins with higher stages of disease in females. In males, the expression of $E R \beta$ mRNA in cancer tissue shows a similar decrease in CRC compared with healthy tissues in all stages of disease. This finding is in agreement with our observation that $E R \beta$ mRNA expression correlates with survival in females but not in males (Hasakova et al. 2018).

Since the discovery of ER $\beta$, several studies have investigated its expression in cancer tissue compared with adjacent tissues. While early studies did not reach a definitive conclusion concerning this issue, lately, a consensus has begun to arise. A decrease in $E R \beta$ expression in colorectal cancer compared with adjacent tissues was observed previously in males and females (Mostafaie et al. 2009) at the protein and mRNA levels (Williams et al. 2016, Ya et al. 2017). Sex-dependent changes in ER $\beta$ protein expression in CRC have been reported (Nüssler et al. 2008) in agreement with our present findings. High $E R \beta$ mRNA expression was associated with better survival in females but not males (Hasakova et al. 2018). On the contrary, sex-dependent differences in ER $\beta$ expression associated with survival were not observed in the pathology atlas (Uhlen et al. 2017). We suppose that discrepancies with respect to $E R \beta$ expression in CRC may be caused by alternative splicing of $E R \beta$ (Castiglione et al. 2008, Hua et al. 2018) and by race-dependent differences in CRC incidence and mortality (Alshareef et al. 2019).
The reported decrease in $E R \beta$ mRNA expression in $\mathrm{CRC}$ in females is in accordance with the finding that $E R \beta$ expression decreased progressively in female patients with nodus involvement and more advanced clinical stages. In males we only observed a decreasing trend in $E R \beta$ expression in patients with large tumors. Our data are in accordance with a previously observed inverse correlation between $E R \beta$ expression with increasing tumor staging (Rudolph et al. 2012, Williams et al. 2016). In addition, a study using the gene signaturebased BinReg approach to semiquantitatively analyze estrogen receptor (ER) pathway activity in multiple CRC cohorts indicated that the ER pathway is significantly inversely associated with CRC recurrence in patients in stage II (Liu et al. 2016).

The reason why ERß expression in CRC is decreased compared with adjacent tissues has not been completely elucidated. Regulation of ER $\beta$ is complex and involves alternative splicing, transcription factors and post-transcriptional regulation (Hua et al. 2018). miRNAmediated regulation was implicated as the reason for decreased $E R \beta$ in CRC, as dual luciferase reporter assays pointed to $E R \beta$ as a direct target gene of miR-129, which was shown to inhibit $E R \beta$ expression and thereby enhance colon cancer cell proliferation and migration (Ya et al. 2017). In addition to the above mentioned $E R \beta$ regulatory factors, a circadian system also contributes to regulation of $E R \beta$ expression via E-box (Cai et al. 2008). $E R \beta$ shows a rhythmic pattern of expression in cultured cells and mouse tissues, and the daily rhythm disappears in BMAL1 knockout mice (Swedenborg et al. 2009).

In our study clock gene expression also exerted sex-dependent regulation. We observed a positive correlation between PER2 and CRY2 mRNA and ER $\beta$ in the proximal healthy tissue in male patients. No such correlation was observed in cancer tissue. Interestingly, we did not observe a correlation between any analyzed 
clock genes and $E R \beta$ expression in female patients in either cancer or proximal tissue. Recent findings are in accordance with a previous report of sexual dimorphism in gene expression in CRC. Core clock genes PER2 and $C R Y 2$ exerted a more pronounced decrease in cancer tissue than in healthy tissues in males compared with females (Hasakova et al. 2018). Similarly, expression of miRNAs miR-16 and miR-21 showed sex-dependent differences in expression in cancer compared with healthy tissue (Hasakova et al. 2017). The reason why a circadian oscillator shows a tighter relationship with $E R \beta$ expression in males in comparison with females is not clear, but it is in accordance with the previous observation that chronomodulated chemotherapy is more beneficial for male than for female patients (Giacchetti et al. 2012).

$E R \beta$ also mediates estrogen effects related to tumorigenesis via inhibition of VEGF-A expression (Hartman et al. 2006, Yang et al. 2013), which can contribute significantly to its tumor suppressor capacity. Our results indicate that this regulation can occur at the transcriptional level, as we observed a negative correlation between $E R \beta$ and $V E F G-A$. This is possible because the $V E F G$ gene contains estrogen response elements in its sequence (Hyder et al. 2000). Surprisingly, $E R \beta$ showed a negative correlation with $V E G F-A$ expression in females without nodus involvement and in men with more advanced cancer stages. A possible explanation for this observation is that androgen signaling, which also differs between the two genders, influences angiogenesis in a sex-dependent way and is more efficient in males than in females (Sieveking et al. 2010). This observation is in accordance with the finding that $V E G F-A$ expression in colorectal cancer tissue was associated with worse survival in males but not in females (Hasakova et al. 2018).

Limitations of the present study issue mainly from scarce information about sex hormones (and particularly estrogen) in the circulation of patients. It is difficult to estimate levels of sex hormones from references about the adult population because the average age of patients undergoing surgery for CRC is above 65 years (Uhlen et al. 2017), an age at which pronounced endocrine changes occur. A whole spectrum of sex hormones, their metabolites and their corresponding receptors would certainly improve our knowledge about sex-hormone-induced changes in CRC and its progression.

To conclude, in female patients, expression of $E R \beta$ mRNA decreased with increasing TNM stage. This dependence of $E R \beta$ expression on TNM staging was not observed in males. TNM staging was not associated with the expression of $E R \beta$ in healthy tissues. $E R \beta$ expression correlated with clock gene expression in the proximal tissues in male but not female patients, and this correlation was lost in cancer tissue. ER $\beta$ mRNA expression was also analyzed with respect to $V E G F-A$ mRNA expression since sex steroid hormones are known to influence angiogenesis, which always accompanies tumor growth. We observed a significant negative correlation between $E R \beta$ and $V E G F-A$ expression only in cancer tissue (not in healthy tissues) in females without nodus involvement and without distant metastases, whereas in male patients this negative correlation was observed in patients with more advanced stages of disease. Our data indicate that during tumorigenesis, $E R \beta$ expression shows sex-dependent differences. In CRC $E R \beta$ seems to mediate tumor suppressor effects; therefore, sex-dependent changes in its expression can probably contribute to the frequently reported differences in incidence and survival between males and females with this disease.

\section{Conflict of Interest}

There is no conflict of interest.

\section{Acknowledgements}

Research was supported by grants APVV-14-0318, APVV-16-0209 and VEGA 1/0679/19.

\section{References}

ALSHAREEF SH, ALSOBAIE NA, ALDEHESHI SA, ALTURKI ST, ZEVALLOS JC, BARENGO NC: Association between Race and Cancer-Related Mortality among Patients with Colorectal Cancer in the United States: A Retrospective Cohort Study. Int J Environ Res Public Health 16: 240, 2019.

BENDARDAF R, EL-SERAFI A, SYRJÄNEN K, COLLAN Y, PYRHÖNEN S: The effect of vascular endothelial growth factor-1 expression on survival of advanced colorectal cancer patients. Libyan J Med 12: 1290741, 2017. 
CAI W, RAMBAUD J, TEBOUL M, MASSE I, BENOIT G, GUSTAFSSON JA, DELAUNAY F, LAUDET V, PONGRATZ I: Expression levels of estrogen receptor beta are modulated by components of the molecular clock. Mol Cell Biol 28: 784-793, 2008.

CASTIGLIONE F, TADDEI A, ROSSI DEGL'INNOCENTI D, BUCCOLIERO AM, BECHI P, GARBINI F, CHIARA FG, MONCINI D, CAVALLINA G, MARASCIO L, FRESCHI G, GIAN LT: Expression of estrogen receptor beta in colon cancer progression. Diagn Mol Pathol 17: 231-236, 2008.

CLAESSON-WELSH L, WELSH M: VEGFA and tumor angiogenesis. $J$ Intern Med 273: 114-127, 2013.

CLOCCHIATTI A, CORA E, ZHANG Y, DOTTO GP: Sexual dimorphism in cancer. Nat Rev Cancer 16: 330-339, 2016.

ENMARK E, PELTO-HUIKKO M, GRANDIEN K, LAGERCRANTZ S, LAGERCRANTZ J, FRIED G, NORDENSKJÖLD M, GUSTAFSSON JA: Human estrogen receptor beta-gene structure, chromosomal localization, and expression pattern. J Clin Endocrinol Metab 82: 4258-4265, 1997.

FOLEY EF, JAZAERI AA, SHUPNIK MA, JAZAERI O, RICE LW: Selective loss of estrogen receptor beta in malignant human colon. Cancer Res 60: 245-248, 2000.

GAUCHER J, MONTELLIER E, SASSONE-CORSI P: MOLECULAR COGS: Interplay between circadian clock and cell cycle. Trends Cell Biol 28: 368-379, 2018.

GEORGE ML, TUTTON MG, JANSSEN F, ARNAOUT A, ABULAFI AM, ECCLES SA, SWIFT RI: VEGF-A, VEGF-C, and VEGF-D in colorectal cancer progression. Neoplasia 3: 420-427, 2001.

GIACCHETTI S, DUGUÉ PA, INNOMINATO PF, BJARNASON GA, FOCAN C, GARUFI C, TUMOLOS, COUDERT B, IACOBELLI S, SMAALAND R, TAMPELLINI M, ADAM R, MOREAU T, LÉVI F: Sex moderates circadian chemotherapy effects on survival of patients with metastatic colorectal cancer: a metaanalysis. Ann Oncol 23: 3110-3116, 2012.

GIROUX V, BERNATCHEZ G, CARRIER JC: Chemopreventive effect of ER $\beta$-Selective agonist on intestinal tumorigenesis in Apc(Min/+) mice. Mol Carcinog 50: 359-369, 2011.

GIROUX V, LEMAY F, BERNATCHEZ G, ROBITAILLE Y, CARRIER JC: Estrogen receptor beta deficiency enhances small intestinal tumorigenesis in ApcMin/+ mice. Int J Cancer 123: 303-311, 2008.

HARTMAN J, EDVARDSSON K, LINDBERG K, ZHAO C, WILLIAMS C, STROM A, GUSTAFSSON JA: Tumor repressive functions of estrogen receptor beta in SW480 colon cancer cells. Cancer Res 69: 6100-6106, 2009.

HARTMAN J, LINDBERG K, MORANI A, INZUNZA J, STRÖM A, GUSTAFSSON JA: Estrogen receptor $\beta$ inhibits angiogenesis and growth of T47D breast cancer xenografts. Cancer Res 66: 11207-11213, 2006.

HASÁKOVÁ K, BEZAKOVA J, VICIAN M, REIS R, ZEMAN M, HERICHOVA I: Gender-dependent expression of leading and passenger strand of miR-21 and miR-16 in human colorectal cancer and adjacent colonic tissues. Physiol Res 66 (Suppl 4): S575-S582, 2017.

HASAKOVA K, VICIAN M, REIS R, ZEMAN M, HERICHOVA I: Sex-dependent correlation between survival and expression of genes related to the circadian oscillator in patients with colorectal cancer. Chronobiol Int 35: 1423-1434, 2018.

HERICHOVÁ I, AMBRUŠOVÁ J, MOLČAN L, VESELÁ A, SVITOK P, ZEMAN M: Different effects of phase advance and delay in rotating light-dark regimens on clock and natriuretic peptide gene expression in the rat heart. Physiol Res 63 (Suppl 4): S573-S584, 2014.

HONMA S: The mammalian circadian system: a hierarchical multi-oscillator structure for generating circadian rhythm. J Physiol Sci 68: 207-219, 2018.

HUA H, ZHANG H, KONG Q, JIANG Y: Mechanisms for estrogen receptor expression in human cancer. Exp Hematol Oncol 7: 24, 2018.

HYDER SM, NAWAZ Z, CHIAPPETTA C, STANCEL GM: Identification of functional estrogen response elements in the gene coding for the potent angiogenic factor vascular endothelial growth factor. Cancer Res 60: 3183-3190, 2000.

KENNELLY R, KAVANAGH DO, HOGAN AM, WINTER DC: Oestrogen and the colon: potential mechanisms for cancer prevention. Lancet Oncol 9: 385-391, 2008.

LIU D: Gene signatures of estrogen and progesterone receptor pathways predict the prognosis of colorectal cancer. FEBS J 283: 3115-3133, 2016. 
MOSSELMAN S, POLMAN J, DIJKEMA R: ER beta: identification and characterization of a novel human estrogen receptor. FEBS Lett 392: 49-53, 1996.

MOSTAFAIE N, KÁllAY E, SAUERZAPF E, BONNER E, KRIWANEK S, CROSS HS, HUBER KR, KRUGLUGER W: Correlated downregulation of estrogen receptor beta and the circadian clock gene Per1 in human colorectal cancer. Mol Carcinog 48: 642-647, 2009.

MURPHY G, DEVESA SS, CROSS AJ, INSKIP PD, MCGLYNN KA, COOK MB: Sex disparities in colorectal cancer incidence by anatomic subsite, race and age. Int J Cancer 128: 1668-1675, 2011.

NIE X, XIE R, TUO B: Effects of estrogen on the gastrointestinal tract. Dig Dis Sci 63: 583-596, 2018.

NÜSSLER NC, REINBACHER K, SHANNY N, SCHIRMEIER A, GLANEMANN M, NEUHAUS P, NUSSLER AK, KIRSCHNER M: Sex-specific differences in the expression levels of estrogen receptor subtypes in colorectal cancer. Gend Med 5: 209-217, 2008.

REESE JM, BRUINSMA ES, NELSON AW, CHERNUKHIN I, CARROLL JS, LI Y, SUBRAMANIAM M, SUMAN VJ, NEGRON V, MONROE DG, INGLE JN, GOETZ MP, HAWSE JR: ER $\beta$-mediated induction of cystatins results in suppression of TGF $\beta$ signaling and inhibition of triple-negative breast cancer metastasis. Proc Natl Acad Sci U S A 115: E9580-E9589, 2018.

RUDOLPH A, TOTH C, HOFFMEISTER M, ROTH W, HERPEL E, JANSEN L, MARX A, BRENNER H, CHANGCLAUDE J: Expression of oestrogen receptor B and prognosis of colorectal cancer. Br J Cancer 107: 831-839, 2012.

SIEGEL RL, MILLER KD, JEMAL A: Cancer statistics, 2015. CA Cancer J Clin 65: 5-29, 2015.

SIEVEKING DP, LIM P, CHOW RW, DUNN LL, BAO S, MCGRATH KC, HEATHER AK, HANDELSMAN DJ, CELERMAJER DS, NG MK: A sex-specific role for androgens in angiogenesis. $J$ Exp Med 207: 345-352, 2010.

SWEDENBORG E, POWER KA, CAI W, PONGRATZ I, RÜEGG J: Regulation of estrogen receptor beta activity and implications in health and disease. Cell Mol Life Sci 66: 3873-3894, 2009.

SYMER MM, WONG NZ, ABELSON JS, MILSOM JW, YEO HL: Hormone replacement therapy and colorectal cancer incidence and mortality in the prostate, lung, colorectal, and ovarian cancer screening trial. Clin Colorectal Cancer 17: e281-e288, 2018.

TORRE LA, BRAY F, SIEGEL RL, FERLAY J, LORTET-TIEULENT J, JEMAL A: Global cancer statistics, 2012. CA Cancer J Clin 65: 87-108, 2015.

UHLEN M, ZHANG C, LEE S, SJÖSTEDT E, FAGERBERG L, BIDKHORI G, BENFEITAS R, ARIF M, LIU Z, EDFORS F, SANLI K, VON FEILITZEN K, OKSVOLD P, LUNDBERG E, HOBER S, NILSSON P, MATTSSON J, SCHWENK JM, BRUNNSTRÖM H, GLIMELIUS B, SJÖBLOM T, EDQVIST PH, DJUREINOVIC D, MICKE P, LINDSKOG C, MARDINOGLU A, PONTEN F: A pathology atlas of the human cancer transcriptome. Science 357: 2507, 2017.

WADA-HIRAIKE O, IMAMOV O, HIRAIKE H, HULTENBY K, SCHWEND T, OMOTO Y, WARNER M, GUSTAFSSON JA: Role of estrogen receptor beta in colonic epithelium. Proc Natl Acad Sci U S A 103: 2959-2964, 2006.

WILLIAMS C, DILEO A, NIV Y, GUSTAFSSON JÅ: Estrogen receptor beta as target for colorectal cancer prevention. Cancer Lett 372: 48-56, 2016.

XIE LQ, YU JP, LUO HS: Expression of estrogen receptor beta in human colorectal cancer. World J Gastroenterol 10: 214-217, 2004.

YA G, WANG H, MA Y, HU A, MA Y, HU J, YU Y: Serum miR-129 functions as a biomarker for colorectal cancer by targetingestrogen receptor (ER) $\beta$. Pharmazie 72: 107-112, 2017.

YANG J, XIONG LJ, XU F, ZHAO X, LIU B, CAI KL, WANG GB: Estrogen inhibits colon polyp formation by reducing angiogenesis in a carcinogen-induced rat model. Int J Endocrinol 2013: 453898, 2013.

YANG SL, REN QG, WEN L, HU JL, WANG HY: Research progress on circadian clock genes in common abdominal malignant tumors. Oncol Lett 14: 5091-5098, 2017.

ZEMAN M, VICIAN M, MONOSÍKOVÁ J, REIS R, HERICHOVÁ I: Deregulated expression of the per2 gene in human colorectal carcinoma. Mol Med Rep 1: 599-603, 2008. 